\title{
The influence of engineering infrastructure on the quality of life in Kaunas city
}

\author{
Jūratė Venckauskaitè ${ }^{\mathrm{a}}$, Rasa Ušpalytė-Vitkūnienè ${ }^{\mathrm{b}}$, Rūta Skripkiené ${ }^{\mathrm{a}}$, Vytautas Palevičius ${ }^{\mathrm{a}}$ \\ ${ }^{a}$ Vilnius Gediminas Technical University, Faculty of Environmental Engineering, Research Institute of Territory Planning, \\ Sauletekio av. 11, Vilnius, 10223, Lithuania \\ ${ }^{b}$ Vilnius Gediminas Technical University, Faculty of Environmental Engineering, Department of Urban Engineering, \\ Sauletekio av. 11, Vilnius, 10223, Lithuania
}

\begin{abstract}
This article focuses on the engineering infrastructure indicators and how strong they influence on the quality of life in Kaunas city. Engineering infrastructure becomes more and more important in our everyday life. Such factors like, streets network, density of public transport network, the existence of night public transport service, bicycle paths network and others have big influence to our satisfaction of life factor. The strength of these indicators is analyzed in this article.
\end{abstract}

Keywords: quality of life; engineering infrastructure; public transport.

\section{Introduction, typicality of the problem}

In the European context Lithuanian cities develop rather chaotically and extremely unsteadily. The most topical problems are: when solving urban development tasks, there is a lack of complexity and comprehensively planned residential areas that are equipped with engineering and social infrastructure; Political processes have a considerable impact on the planning. When municipality decision-makers and officers change, the continuity of urban development is not maintained; strategic aims are sacrificed in favour of short-term benefit. Investments into urban development, financing of measures important for the functioning of the city as well as ranking of their priorities are not substantiated; High quality norms of urban territory planning are not available and the systems of the quality of life evaluation and urban development monitoring have not been worked out.

To summarize all problems mentioned above it shall be pointed out that separate urban territories develop unevenly and disparities between them are noticed. Therefore, trends of urban residential areas' development unevenness are distinguished; socially and economically negative territories characterized by extremely low quality of life develop; the threat of cities characterized by considerable economic and social stagnation and ecological instability arises.

To ensure sustainable development of urban territories, focus should be laid on the steady development of acquired territories, determination of development factors and identification of the system of indicators guaranteeing the quality of life. The system of indicators shall cover economic, social, environmental aspects and humanize the existing territories, including indicators which reflect the needs of society and public interest. Urban visions and the creation of urban image shall be based on the evaluation of quality of life in residential areas.

It is considered that housing market is one of the most important indicators reflecting the economic condition of the country. Therefore, these markets are of great interest to researchers, who are trying to identify the factors determining the change of prices in the housing market. There is no doubt about the importance of real estate price being one of the key indicators reflecting the level of urban economic development and quality of life. Therefore, it is important to study the relationship between real estate price and urban quality of life indicators.

The general object of this study is urban areas, their development according to sustainable development principles and the assessment of the consequences. The narrow study object is Kaunas city and its residential areas. The purpose of the research is to establish the pattern of sustainability and well-being in Kaunas city, estimate the factors, and quantify the real estate price relationship with a number of social-economic indicators. For the purpose of the present study the price of

Corresponding author: Rasa Ušpalytė-Vitkūnienė. E-mail address: rasa.uspalyte@vgtu.lt

http://dx.doi.org/10.3846/enviro.2014.139

(C) 2014 The Authors. Published by VGTU Press. This is an open-access article distributed under the terms of the Creative Commons Attribution License, which permits unrestricted use, distribution, and reproduction in any medium, provided the original author and source are credited. 
dwelling in the centre of Kaunas has been chosen as an indicator reflecting the quality of life. Relation of the said indicator has been verified relying on the aspects describing the engineering infrastructure. Moreover, some social economic aspects have also been included. However, due to a shortage in the related data in the process of the research, it has been decided by the researchers, that the group of indicators should be limited to the indicators typical of the communication infrastructure. Basically, the following indicators have been assessed: population density, work place density, street density, maximum flows of cars, bus route density, trolley-bus route density, bus night services, trolleybus night services, cycling paths density.

\subsection{Quality of Life Concept}

As a result of movement of rural population to urban areas during the period of the recent 50 years, city has become a nucleus of population occupation, incubator for the state of the art technologies, portal to the rest of the world, centre of education and a place of: supply of social services and shelter, processing of agricultural products, creation of production added value and, which is the most important, a place where one can earn on the basis of trade/commerce, industry, finance, real estate and, among other things, delinquency and corruption [1]. A concept of sustainability as a strategy of urban and rural development has never ever been that widespread [2]. All the same, numerous descriptions of sustainability and sustainable development do exist [3]. For example, a description of sustainable development given by Hediger [4] is very similar to that of Brundtland's Commission viz., it is a development which meets the needs of current generations without compromising the ability of future generations to meet their own needs. A concept of a sustainable city according to Rogers [5] must be in line with social, environmental, political, cultural and economic objectives. Following Rogers et al, the abovementioned elements of sustainable urban development might also be considered as the elements of urban life quality $[1,5]$. For the reason, studies of urban life quality tend to attract more and more attention of scientists, urban developers and politicians.

Versatile interpretations and assessments of this phenomenon reveal a vast scientific interest in the accomplishment of life quality studies though at the same time the scientists are concerned indeed about inability to agree on a unanimous/single life quality concept and the main dimensions/parameters to be employed in the life quality assessment [6].

The significance of the said studies is also revealed by the fact that urban life quality is more and more viewed as an essential driving force for urban development. It is maintained by Florida [7] that in the economic context of a city, the city's population is more significant than the activities of institutions or industries therein and a correct policy of urban strategy should attract creative and educated people by improving conditions of their life. As generalized by Trip [8], the quality of the local level is of critical significance - an attractive, versatile and tolerant urban environment is often highlighted as a critical indicator of competitiveness of a city. Such considerations bring more challenges for city management since the resources are limited and the politicians need to find the most effective ways and solutions and to decide on optimal allocation of these based on the population demands and priorities [9]. According to Pacione [10], the key task in the investigations of life quality is the determination of multivariate aspects of urban environment quality and wellbeing of individuals.

Life quality is treated as quality of urbanized environment, suitability to live, quality of location, perception of life, satisfaction and stability. Considering emphasis on different aspects of urban life quality made by different sciences and substantiation of these pursued by different notions and theories, it was identified by Van Kamp et al. [11], that no exhaustive conceptual model or a system of indicators to assess life quality has been developed. Though a common agreement on life quality description is missing, the majority of scientists agree about life quality being a multivariate concept which encompasses psychological, economic, social and physical well-being aspects.

A notion of life quality is far from being a novelty in the scientific literature of Lithuania however, the related researches are lacked. Articles dealing with life quality parameters and the programme for their improvement within an overall plan of the territory of Lithuania were published by Vanagas, Vilnius Gediminas Technical University scientist [12-13]. Again, professor Juškevičius of Vilnius Gediminas Technical University stimulated the creation of a system of indices and to improve it and to start using it for urban planning purposes [14-15]. A tangible input in sustainable urban development and life quality studies in the cities and regions of Lithuania has been made by the publications of Burinskiene and Rudzkiene [16-21].

A survey of scientific literature shows that the definition of life quality is of utmost complexity despite numerous attempts made by scientists. Probably the definitions of life quality notion are not that interesting by themselves, but its meaning is reflected by their interpretations.

\subsection{Measurement of Quality of Life}

The majority of authors regard the use of indicators as a definition of sustainable development concept. The indicators involved in sustainability assessment also trace and appraise certain aspects of sustainability policy and enable observation of development and control over it [22]. In taking strategic decisions important to a city and its agglomeration, this tool is also employed to determine a level of progress of the city, deviations, effectiveness of the ongoing implementation of plans and programmes [23]. Nowadays, in dynamic urban development process, where different actors of this process strive for satisfying the sole interests of their own, the city indicators may be considered as an instrument for taking of subservient 
decisions. No matter a vast potential is observed for interconnection of indicators to be relied on for the development, supervision and review of urban development projects, the related scientific studies are still scarce [24].

Physical environment has a significant influence on well-being of individuals as well. An opinion prevails, that top quality physical environment has direct impact on high quality of life in the cities. This works only in the cases, when the physical environment satisfies daily needs of individuals and makes their expectations to come true. Indicators of physical environment often depict the social and engineering infrastructure of the cities allowing people to satisfy their daily needs in the city.

Urban life quality analyses are not new and for the sake of life quality description quantitative measurement tools and qualitative description are used along with attitude clarification and natural properties of the environment/surroundings [25]. However, practical application of the outcome of analyses is more complex and life quality is assessed from different perspectives, viz., physical layout o the city, its infrastructure, economic impact, governmental policy, public opinion and social remuneration. The substance of scientific studies is witnessed by an unavailability of a simple model to be discovered in order to assess all factors influencing the life quality and a subsequent forecasting method/way. Thus it is important to select effective indicators to properly describe urban environment quality and to serve as an effective means for sustainable cities planning. Advantages of application of DEA methods in models have been pointed out by Bougnol et al. [26].

No examples of use of the integrated system of urban development indices in Lithuanian practice have been witnessed. However, the launch of investigation and practical application of the indictor system and its key principles is with Juškevičius. For the elaboration of general territory plans for three Lithuanian district municipalities in 2004, he proposed an original system for the present condition assessment and in the preparation of general plan for the city of Vilnius, creation of a comprehensive system of indicators was commenced [14]. Data of Vilnius population opinion pools used to be investigated by the Lithuanian scientists Zavadskas, Šaparauskas, Viteikiene [27-28]. The investigation was based on the indicator values defined by expert surveys. Moreover, the so-called CORPAS, Complex Proportional Assessment was relied on to determine priority ranking of residential areas/blocks in terms of their sustainability. It is proposed by Jakimavičius and Burinskiene, that an accessibility factor based on the city transport system analysis and GIS (geographic information system) computation method should be used for determination of problematic transport zones in Vilnius city [29].

\subsection{Life quality versus real estate price}

Housing and life quality are closely interconnected with sustainability. A share of the society the conditions of life of which are poor indeed is primarily dependent on environmental impact problems, as it has the least possibilities to cope with them. The improvement in life conditions leads to the increase in the subsistence costs and population mobility. People move to a higher quality and better dwelling, thus an increase in the use of natural resources and energy and in the amounts of produced waste follows. The improving quality of life allows to disregard or avoid some adverse consequences to the environment to some extent [16-21].

A picture of a modern city constitutes the layout of enterprises and offices, routes of the extending mains and a visual aesthetic view. As indicated by real estate specialists, attractiveness of historical city centers as places for dwelling tends to reduce. The city districts/areas with unique architecture and high comfort level of dwelling premises become the most attractive or prestigious. Low air pollution is viewed as one of the main factors of attractiveness. Nonetheless, the location of the city district, which is decisive for dwelling environment quality, is the top factor taken into account [30]. Some researchers assume that a marginal wish of consumers to pay for environment planning decreased during the economic downturn in 2008, comparing with real estate prosperity during the period of 2000-2006 [31]. Thus it is worthwhile mentioning, that for the sake of environment quality improvement systematic and concentrated attempts are required to arranged functionally and socially integrated urban and the planned area/territory structure and to form integral and compact structural units of territories [32].

\section{Kaunas city communication system}

Due to small distances and strategically convenient position in terms of high category international motorways and railways, Kaunas city is well integrated into both, an overall access communication system of Lithuania and an international network of transport corridors. A level of urban communication infrastructure development is among the key indicators ensuring economic, social and economic activities of the city and region due to transportation of passengers and freight. Kaunas is one of the most compact cities in Lithuania with the major share of the territory population, i.e. 96.5 percent, accessible within $7 \mathrm{~km}$ radius from geometric city center with its population making 2146 inhabitants $/ \mathrm{km}^{2}$. Almost half of the city territory is built-up and the density of street network makes $5.85 \mathrm{~km} / \mathrm{km}^{2}$. Thus advantageous opportunities are available for efficient distribution of traffic flows and selection of travelling mode, as well as length and duration of a trip. Urban structure of Kaunas has formed the specifics of communication system operation and mobility habits for Kaunas inhabitants.

The direction of sustainable urban development constantly emphasizes a model of a compact city, limitation of urbanized expansion into suburbs, densification and upgrade of the city internal areas/territories and the significance of multifunction of the city territories. If these principles are disregarded, safeguarding of effective access communication in cities becomes impossible to achieve. Traffic congestion becomes an inseparable part of city life and the issued of high communications 
costs, ecological pollution and increased accident rate are faced. Moreover, large investments are needed for a widely sprawled city with low population density and later on it will develop into demand for large operational costs associated with infrastructure and supply of public transport services.

A general level of mobility during the recent 30 years failed to undergo any essential changes and varied between 2.8 and 2.9 passengers/day. In principle, it is transport mode dependent mobility of population changes rather than an overall mobility of people. The increasing trip length due to periphery development leads to decreasing number of trips on foot. An assumed overall mobility of population in the future plans of Kaunas city communication system opts for 3.0 passengers/day.

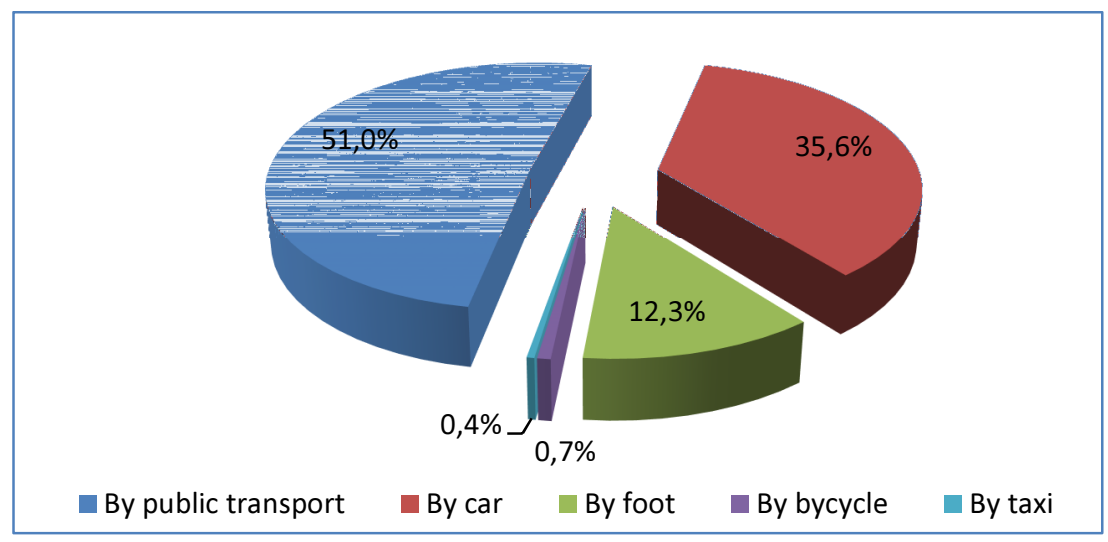

Fig. 1. Distribution of travelling mode in Kaunas during rush hour

Community surveys in the form of questionnaires revealed public transport to keep its dominant position in the structure of travelling modes. Irrespective of a decreased share of trips by public transport from 60 to 51 percent during the last decade (Fig. 1), the positions held by public transport are high enough and meet the principles of sustainable development. A number of trips by cars increased from 22.5 to 35.6 percent and tends to increase further especially due to tendencies of urban development towards suburbs. A number of pedestrian trips reduced from 19.5 to 12.3 percent [33-34]. Prospective distribution of trip modes in percent will primarily depend on the urban development management in the city and formation of communication system policy.

Three main public transportation modes are available in Kaunas: buses, trolleybuses and privately operated minibuses. Trolleybus system covers 15 routes (and 2 night routes) situated within the main part of the city. If a closer look to the bus and trolleybus routes is taken, it would be discovered that the main routes of buses extend in the city districts/areas which are densely populated and not serviced by trolleybuses. The system is supplemented with 23 small-volume routes. The analysis of a number of routes of different transport mode types revealed the main corridors to be the same. It is the northern part of the city with the prevailing high-rise multi-apartment buildings with the most population choosing public transport to go to work.

Considering the volume/number of passenger in public transport (PT) means, trolleybuses and diesel fuel driven buses are larger than minibuses thus minibuses are not that important in terms of the system volume. The activities of private minibuses are commercial/profit based thus they operate in mostly loaded corridors. The structure of private minibuses is very clear, they take routes to dwelling districts/areas in the north west and north east. In the south of the city trips of private minibuses are not numerous.

A network of public transport routes consists of quite a lot of lines and sometimes their arrangement seems illogical or difficult to understand, for the city visitors in particular. The route system is based on direct routes extending between dwelling and working places aiming at the least possible number of transfers.

\section{Identification of indicators that influence Quality of life in Engineering infrastructure area}

In order to conclude an empiric model for factors that have influence on the passenger flows of public transport, the programme Statgraphics was used, in which all the dependency models were assessed with the reliability of $90 \%-99 \%$. Picked factors were analysed in 32 transport districts of the Kaunas city, based on a theoretical research of public transport services (like route density and night services) and main economic indicator which reflect quality of life- dwelling price.

By using the Statgraphics programme a statistical analysis was carried out of the indicators on which quality of life depend. The analysed indicators can be divided into 3 groups: urban structure, public transport services and economic group (Table 1).

The group of urban structure indicators covers the density of inhabitants and working places, making the effect on the total mobility of inhabitants and comfort sense by living, which in the studied districts varies from 25 working places $/ \mathrm{km}^{2}$ to 6745 working places $/ \mathrm{km}^{2}$ (in the centre). The indicators also include the street density of the district. This group of indicators shows the demand for transport system in the studied transport district of the Kaunas city. 
Table 1. Description of the studied indicators

\begin{tabular}{|c|c|c|}
\hline Group & Indicator & Abbreviation \\
\hline \multirow{3}{*}{ Urban structure } & Population density, inhab./km & $P D$ \\
\hline & Work place density, wrk.pl./km ${ }^{2}$ & $W P D$ \\
\hline & Street density, $\mathrm{km} / \mathrm{km}^{2}$ & $S D$ \\
\hline \multirow{6}{*}{ Transport services } & Maximum flows of cars, cars/h & $M F C$ \\
\hline & Bus route density, $\mathrm{km} / \mathrm{km}^{2}$ & $B R D$ \\
\hline & Trolley-bus route density, $\mathrm{km} / \mathrm{km}^{2}$ & $T b R D$ \\
\hline & Bus night services, $\mathrm{km} / \mathrm{km}^{2}$ & $B n S$ \\
\hline & Trolleybus night services, $\mathrm{km}^{2}$ & $T b n S$ \\
\hline & Cycling paths density, $\mathrm{km} / \mathrm{km}^{2}$ & $C D$ \\
\hline Economic & Dwelling price, $\mathrm{LT} / \mathrm{m}^{2}$ & $D P$ \\
\hline
\end{tabular}

The indicators of public transport services, which describe accessibility indices of public transport routes, include their density and night services in a transport district. These indicators are very different in each of the studied transport districts; in the central and middle part of the city they ensure a high level of public transport service, while in a periphery - only the indispensable service level.

The economic indicator, which in author opinion is the main factor which could reflect the quality of life in the district, is dwelling price. This price for one square meter shows how much inheritance wants to pay for living possibility in analysing district.

Binominal regression of the indicators. For the analyses of the selected indicators, binominal regression has been investigated in the first place, i.e. to see the way the indicators influence each other. A matrix contained in Table 2 has been developed from correlation coefficients of the binominal regression dependence models.

Table 2. Correlation coefficients between indicators

\begin{tabular}{l|l|l|l|l|l|l|l|l|l|l}
\hline & PD & WPD & SD & CD & TbRD & TbnS & BRD & BnS & MFC & DP \\
\hline PD & 1 & 0.26 & 0.16 & 0.01 & 0.41 & 0.37 & $\mathbf{0 . 5 4}$ & 0.42 & 0.24 & 0.22 \\
\hline WPD & 0.26 & 1 & 0.25 & 0.42 & $\mathbf{0 . 6 7}$ & $\mathbf{0 . 6 0}$ & 0.31 & $\mathbf{0 . 5 1}$ & $\mathbf{0 . 5 2}$ & 0.44 \\
\hline SD & 0.16 & 0.25 & 1 & 0.21 & 0.22 & 0.19 & 0.30 & 0.20 & 0.30 & 0.27 \\
\hline CD & 0.01 & 0.42 & 0.21 & 1 & 0.26 & 0.31 & 0.15 & 0.20 & 0.30 & 0.47 \\
\hline TbRD & 0.41 & $\mathbf{0 . 6 7}$ & 0.22 & 0.26 & 1 & $\mathbf{0 . 8 3}$ & 0.38 & 0.38 & 0.46 & 0.29 \\
\hline TbnS & 0.37 & $\mathbf{0 . 6 0}$ & 0.19 & 0.31 & $\mathbf{0 . 8 3}$ & 1 & 0.26 & 0.27 & $\mathbf{0 . 5 1}$ & 0.40 \\
\hline BRD & 0.54 & 0.31 & 0.30 & 0.15 & 0.38 & 0.26 & 1 & $\mathbf{0 . 5 6}$ & 0.28 & 0.21 \\
\hline BnS & 0.42 & $\mathbf{0 . 5 1}$ & 0.20 & 0.20 & 0.38 & 0.27 & $\mathbf{0 . 5 6}$ & 1 & 0.39 & 0.25 \\
\hline MFC & 0.24 & $\mathbf{0 . 5 2}$ & 0.30 & 0.40 & 0.46 & $\mathbf{0 . 5 1}$ & 0.28 & 0.39 & 1 & 0.46 \\
\hline DP & 0.22 & 0.44 & 0.27 & 0.47 & 0.29 & 0.40 & 0.21 & 0.25 & 0.46 & 1 \\
\hline
\end{tabular}

Correlation coefficients reveal a strong logical relation between density of routes of buses and night services of buses and between density of routes of trolleybuses and their night services. This relation is logical indeed as night routes are planned for the city districts/areas with the highest need for public transport. Also, a relation between population density and bus routes density is observed as the network of bus routes is the main public transport network in Kaunas city. Workplace density, highlighting the biggest attraction objects in the city, markedly correlates with all indictors reflecting all transport means - in the network of buses and trolleybuses and with maximum transport flows.

The highest correlation of dwelling price with workplace density, cyclist paths density, night routes of trolleybuses and maximum transport flows is noticed. Coefficient of inter-correlation of these models is found to be over 0.4 , but no essential relation has been observed so far.

\section{Determination of polynomial models}

A polynomial linear regression model is created by searching for a statistical relationship between the dependent variable $y$ - passenger flow of public transport and independent variables $x_{1}, x_{2}, \ldots x_{m}$, Eqn (1).

$$
y=\alpha+\beta_{1} x_{1}+\beta_{2} x_{2}+\ldots \beta_{n} x_{m}+\varepsilon,
$$


where: $\alpha$-constant, $\beta_{1}, \beta_{2}, \ldots \beta_{n}$ constants of a regression model, and $\varepsilon$-random error. In solving the question the change of which indicator tend to be associated with the change in the others, the Pearson's sample correlation coefficient $R$ was used, Eqn (2):

$$
R=\frac{\sum x y-m \overline{x y}}{\sqrt{\left(\sum x^{2}-m \bar{x}^{2}\right)\left(\sum y^{2}-\bar{y}^{2}\right)}},
$$

where: $\bar{x}, \bar{y}$ - arithmetical mean of variables $x$ and $y$. To determine the relationship between more than two variables in a multiple regression the sample multiple coefficient of determination $-r^{2}$ was used, Eqn (3):

$$
r^{2}=\frac{\sum(\hat{y}-\bar{y})^{2}}{\sum(y-\bar{y})^{2}} .
$$

A multiple correlation coefficient indicates a fraction of the total variation of $y$, determined by a regression equation $r=\sqrt{r^{2}}$ Significance of correlation coefficient is tested with t-statistics, Eqn (4):

$$
t=r \sqrt{\frac{n-2}{1-r^{2}}},
$$

where $r$-estimated value of correlation coefficient; $(n-2)$ - degrees of freedom of the Student's distribution.

Reliability of a regression curve is evaluated by testing the probability $\mathrm{P}$ of the null hypothesis (that variables are independent), based on which the hypothesis is accepted or rejected. The significance level $\alpha$ shows the impossibility of the event. A computer-based data analysis estimates the lowest level of significance - p-value, at which a true null hypothesis in a study case could be rejected.

When the probability of erroneous solution is equal to $\alpha$, the probability of a true solution is (1- $\alpha)$, usually expressed in percent. If the p-value is rather low, the null hypothesis is rejected [35-36].

Polynomial regression of dwelling price. Taking into consideration the attitude of the inhabitance, the indicators, that in transport system infrastructure have influence on dwelling price, were selected, such as density of streets and public transport routes, density of cycle pats routes and maximum traffic flows in the streets.

The obtained polynomial regression equation reveals the dependency of dwelling price on the working place density, cycle paths density, trolleybus night services and maximum car flows in the streets of districts (8).

$$
D P=1531.99+0.040 * W P D+4895.68 * C D+92.22 * T b n S+0.082 * M F C .
$$

The obtained coefficient of determination 0.66 shows that the linear regression model explains $66.21 \%$ of dispersion of the studied factors with respect to dwelling price. Reliability level of a regression equation model of dwelling price - $95 \%$.

Direct dependency of dwelling price on the working place density shows that the time spending for the trim to work and back it is important to the citizens'. The density of cycling paths and the trolleybus night service indicators existing in the model could show that the planners are usually trying to plan such services in the city center where the passengers' flows are higher and the demand for the public transport and cycling paths are higher.

Since the square of the correlation coefficient of all polynomial regression equations is 0.6 , it could be stated that the regression equations include the key factors making the influence on dwelling prices.

\section{Conclusions}

1. The survey of the available written sources leads to a conclusion that the analyses of quality of life are most often associated with the reduction of differences between individuals, communities or cities and selection of means and ways/methods to achieve this goal. Moreover, scientist and politicians disagree about a common and precise definition of life quality, its constituents and actual ways to achieve high quality of life in cities. Just a common tendency is found that a notion of life quality is associated with a 'result' - economic, environmental, social, aesthetic or civil, or with a 'reason' of an actual well-being or attractiveness of location.

2. Assessment of the use of indicators is complex enough since attempts are made to perceive clear links between the changes pertaining to determination of indictors, making of actual decisions and political results. The current scientific research activities are directed towards determination of indictors, assessment of links among indicators and analyses of the results sought.

3. Correlation coefficients reveal a strong logical relation between density of routes of buses and night services of buses and between density of routes of trolleybuses and their night services. This relation is logical indeed as night routes are planned for the city districts/areas with the highest need for public transport. 
4. The highest correlation of dwelling price with workplace density, cyclist paths density, night routes of trolleybuses and maximum transport flows is reported. Coefficient of inter-correlation of these models is found to be over 0.4 , but no essential relation has been observed so far.

5. The obtained polynomial regression equation reveals the dependency of dwelling price on the working place density, cycle paths density, trolleybus night services and maximum car flows in the streets of districts. Since the square of the correlation coefficient of all polynomial regression equations is 0.6 , it could be stated that the regression equations include the key factors making the influence on dwelling prices.

\section{References}

[1] Egger, S. 2006. Determining A Sustainable City Model, Environmental Modelling \& Software 21(9): $1235-1246$. http://dx.doi.org/10.1016/j.envsoft.2005.04.012

[2] Gibbs, D.; Krueger, R. 2007. The Sustainable Development Paradox. Urban Political Economy in the United States and Europe, Guildford Press, New York.

[3] Ho, M. W.; Ulanowicz, R. 2005. Sustainable systems as organisms?, Biosystems 82(1): 39-51. http://dx.doi.org/10.1016/j.biosystems.2005.05.009

[4] Hediger, W. 2000. Sustainable development and social welfare, Ecological Economics 32(3): 481-92. http://dx.doi.org/10.1016/S09218009(99)00117-2

[5] Rogers, R. 1998. Cities for a Small Planet, Westview Press.

[6] Morais, P.; Camanho, A. S. 2011. Evaluation of performance of Europen Cities with the aim to promote quality of life improvements, Omega 39(4): 398-409. http://dx.doi.org/10.1016/j.omega.2010.09.003

[7] Florida, R. 2002. The rise of the creative class. New York, Basic Books.

[8] Trip, J .J. 2007. Assessing quality of place: a comparative analysis of Amsterdam and Rotterdam, Journal of Urban Affairs 29(5):501-17. http://dx.doi.org/10.1111/j.1467-9906.2007.00362.x

[9] Ulengin, B.; Ulengin, F.; Guvenc, U. 2001. A multidimensional approach to urban quality of life: The case of Istanbul, European Journal of Operational Research 130(2): 361-374. http://dx.doi.org/10.1016/S0377-2217(00)00047-3

[10] Pacione, M. 2003. Urban environmental quality and human wellbeing-a social geographical perspective, Landscape and Urban Planning 65(1-2): 19-30. http://dx.doi.org/10.1016/S0169-2046(02)00234-7

[11] Van Kamp, I.; Leidelmeijera, K.; Marsmana, G.; de Hollanderbet, A. 2003. Urban environmental quality and Human Well-Being Towards a Conceptual Framework and Demarcation of Concepts. A Literature Study, Landscape and Urban Planning 65(1-2): 5-18. http://dx.doi.org/10.1016/S0169-2046(02)00232-3

[12] Vanagas, J. 1997. Gyvenimo kokybès parametrų studija rengiant Lietuvos Respublikos teritorijos bendraji plana. Urbanistika ir architektūra 24(2): 5-14

[13] Vanagas, J. 1999. Gyvenimo kokybès parametru gerinimo programa Lietuvos Respublikos teritorijos bendrajame plane, Urbanistika ir architektūra 23(2): 71-78

[14] Juškevičius, P. 2005. Gyvenimo kokybė ir darnioji plètra urbanistikoje, Urbansitika ir architektūra 29(4): 174-181.

[15] Juškevičius, P.; Burinskienè, M. 2004. Factors of the residential environment in the urban planning, in WHO International Housing \& Health Symposium, 29 September -1 October, Vilnius.

[16] Burinskienè, M.; Rudzkienė,V. 2003. Multiple regression analysis for recognition of significant factors for sustainable development, International Journal of Strategic Property Management 7(3): 144-153.

[17] Burinskienè, M.; Rudzkienè,V. 2004a. Comparison of spatial-temporal regional development and sustainable development strategy in Lithuania, International Journal of Strategic Property Management 8(3): 163-176.

[18] Burinskienè, M.; Rudzkienè,V. 2004b. Recognition of information patterns and key factors for decision making in sustainable development in Lithuania, Aplinkos tyrimai, inžinerija ir vadyba 1(27): 21-27.

[19] Burinskienè, M.; Rudzkienè,V. 2006. Želdynu ịtaka gyvenimo kokybei ir būsto kainai Vilniuje, Urbanistika ir architektūra 30(1): 30-37.

[20] Burinskiene, M.; Rudzkiene, V. 2007b. Variability and the relationship between quality of life and real estate prices in Lithuania, International journal of environment and pollution 30(3/4): 501-517. http://dx.doi.org/10.1504/IJEP.2007.014825

[21] Burinskienè,M.; Rudzkienė,V. 2009. Future insights, scenarios and expert method application in sustainable territorial planning, Technological and Economic Development of Economy: Baltic Journal on Sustainability 15(1): 10-25. http://dx.doi.org/10.3846/1392-8619.2009.15.10-25

[22] Mazza, L.; Rydin, Y. 1997. Urban sustainability: discourses, networks and policy tools, Progress in Planning 47(1): 1-74. http://dx.doi.org/10.1016/S0305-9006(96)00006-2

[23] Cavric B.; Toplek S.; Siljeg A. 2008. Participatory measurements of sustainable Urban development and quality of life in post - socialist Zadar, Croatia, Spatium 17(18): 45-54. http://dx.doi.org/10.2298/SPAT0818045C

[24] Revi, A.; Dube, M. 1999. Indicators for urban environmental services in Lucknow - process and methods, Environment and Urbanization 11(3): 227245. http://dx.doi.org/10.1177/095624789901100218

[25] Liang, B.; Weng, Q. 2011. Assessing Urban Emnvironmental Quality Change of Indianapolis, United States, by the Remote Sensing and GIS Integration, Applied Earth Observations and Remote Sensing 4(1): 43-55. http://dx.doi.org/10.1109/JSTARS.2010.2060316

[26] Bougnol, M. L.; Duka J. H.; Estellita Lins, M. P.; Moreira da Silva, A. C. 2010. Enhancing standard performance practices with DEA, Omega 38(2): 33-45. http://dx.doi.org/10.1016/j.omega.2009.02.002

[27] Viteikienė, M.; Zavadskas, E. K. 2007. Evaluating the sustainability of Vilnius city residential areas, Journal of Civi Engineering and Management $13(2): 149-155$.

[28] Zavadskas, E.; Viteikienè, M.; Šaparauskas, J. 2007b. Sustainable development assessment of cities and their residential districts, Ekologija 53: 4954.

[29] Jakimavičius, M.; Burinskiene, M. 2009. A GIS and multi-criteria-based anglysis and ranking of transportation zones of Vilnius city, Technological and Economic Development of Economy 15(1): 39-48. http://dx.doi.org/10.3846/1392-8619.2009.15.39-48

[30] Burinskienè, M.; Rudzkienè, V.; Venckauskaite, J. 2011. Effects of Quality of Life on the Price of Real Estate in Vilnius City, International Journal of Strategic Property Management 15(3): 295-311. http://dx.doi.org/10.3846/1648715X.2011.617857

[31] Seong-Hoon, C.; Seung Gyu, K.; Roland, K. R. 2011. Values of environmental landscape amenities during the 2006 real estate boom and subsequent 2008 reces-sion, Journal of Environmental Planning and Management 54(1): 71-91. http://dx.doi.org/10.1080/09640568.2010.502760

[32] Motieka, S. 2009. Besiformuojančio Vilniaus moderniojo centro urbanistinis modelis/Urban model of the orming modern centre of Vilnius. Urbanistika ir Architektūra Journal 33(4): 195-210. http://dx.doi.org/10.3846/13921630.2009.33.195-210

[33] General Kaunas city plan, 2003. Kaunas municipality (in Lithuanian).

[34] General Kaunas city plan, 2013. Kaunas municipality (in Lithuanian). 
[35] Rudzkienè, V. 2005. Social statistic (Socialinè statistika). Vilnius: Mykolo Riomerio leidybos centras. 257 p. (in Lithuanian).

[36] Ušpalytė-Vitkūnienè, R.; Burinskienè, M., 2007. Determination of factors that influence public transport, in Urban transport XIII: urban transport and the environment in the $21^{\text {st }}$ century. Southampton: WIT Press. 96: 327-336. 